\title{
The Development Of Vehicle Management System Textbook Based On Simulation Softwares
}

\author{
Wachid Yahya ${ }^{1}$, Dwi Iskandar ${ }^{2}$ \\ ${ }^{1}$ Automotive Engineering, Polytechnic Indonusa, J1. KH. Samanhudi No.31, Surakarta \\ ${ }^{2}$ Informatics Management, Polytechnic Indonusa, J1. KH. Samanhudi No.31, Surakarta \\ Email :wachidyahya@poltekindonusa.ac.id
}

\begin{abstract}
This study was designed to develop textbook of vehicle management system based on simulation softwares. The research method used Research and Development (R\&D) with a model developed by Dick and Carry, an ADDIE development model that contains five tools; device analysis, design, development, implementation, and evaluation. Analysis of the data used descriptive method. Ther research subjects were the second semester students of the D3 Automotive Engineering Study Program of the Indonusa Polytechnic of Surakarta academic year 2018/2019. The results of this study were the creation of textbooks Vehicle Management Systems integrated with simulation softwares, which were Proteus version 7.07 and Fluidsim version 3.6. The textbook was assessed by 3 learning device experts, 3 lecturers and has been tested on students. The assessments show the percentage of achievements of $92.94 \%$ of the material experts, $86.03 \%$ of the learning device experts, $85.07 \%$ of the lecturers, and $86.62 \%$ of the students. This textbook has advantages from aspects of learning that are in accordance with learning 4.0, namely by combining theory and simulation that can be accessed via smart phones or computers connected to the internet.
\end{abstract}

Keywords:development, textbooks, simulation software

\section{INTRODUCTION}

Industrial revolution 4.0 era requires technological advances to enable automation in almost all fields. New technologies and approaches that combine the physical, digital and biological world will fundamentally change the patterns of life and human interaction. Industrial revolution 4.0 as a phase of the technological revolution changes the way in which human activities take place in scale, scope, complexity, and transformation from previous life experiences. The world of education must immediately respond quickly to these technological changes (Kagermann, 2013).

Industrial revolution 4.0 is based on three main areas which are digital: including big data, IoT, artificial intelligence (AI); biotechnology: applications in education, agriculture, fisheries, medicine, food processing, environmental protection, renewable energy, chemicals and materials; physics: new generation robots, self-driving cars, new materials, nanotechnology (Thai, 2017). The concepts and teaching methods to prepare students to study Industral 4.0 such as the building blocks of digital and virtual industries, (Industrial Internet of Things IIoT), which are interconnected through several communication and information networks including internet (Wermann, 2019). Collaboration in the community provides businesses with a variety of innovative applications along the life product and production processes based on digital data, information and services (Klingenberg, 2017).

In line with the concept of the industrial revolution 4.0, the education system in campus also has to adjust quickly. Given the campus is a place to print a generation that has competence as experts who are ready to jump in the industry. The automotive sector is one of the aspects that has also been targeted in the industrial revolution era. One of the sciences studied in the automotive field is the vehicle management system, which is how aspects of automotive electronics combined with technology based on the internet.

Yahya (2018) explains that learning in the classroom is required to continue to innovate in an effort to achieve learning objectives. Therefore, the learning strategy in 
lectures is the time to combine theory and practice in a balanced manner in accordance with the needs of technological development and student conditions. The teaching system on campus becomes interesting when students have more involvement in the learning process due to their interest and need for that knowledge. Therefore it is necessary to create an interesting learning material by involving the motor aspects of students. Books become very effective teaching material to always be used in transferring knowledge. Unfortunately, only few books which are created too theoretical and tend to be boring.

In supporting the success of the learning process and in accordance with the concept of the industrial revolution 4.0 it is necessary to compile a textbook based on simulation software. With the incorporation of the concept of learning between knowledge and skills, it will be interesting if students also conduct a simulation through software embedded in the computer from the theory they have learned, so that the expectations will be more effective and the acquired skills can be attached more strong in memory.

\section{RESEARCH METHOD}

This research used research and development (R\&D) method developed by Dick and Carry; the ADDIE development model; which includes analysis, design, development, implementation, and evaluation stages (Mulyatiningsih, 2013).

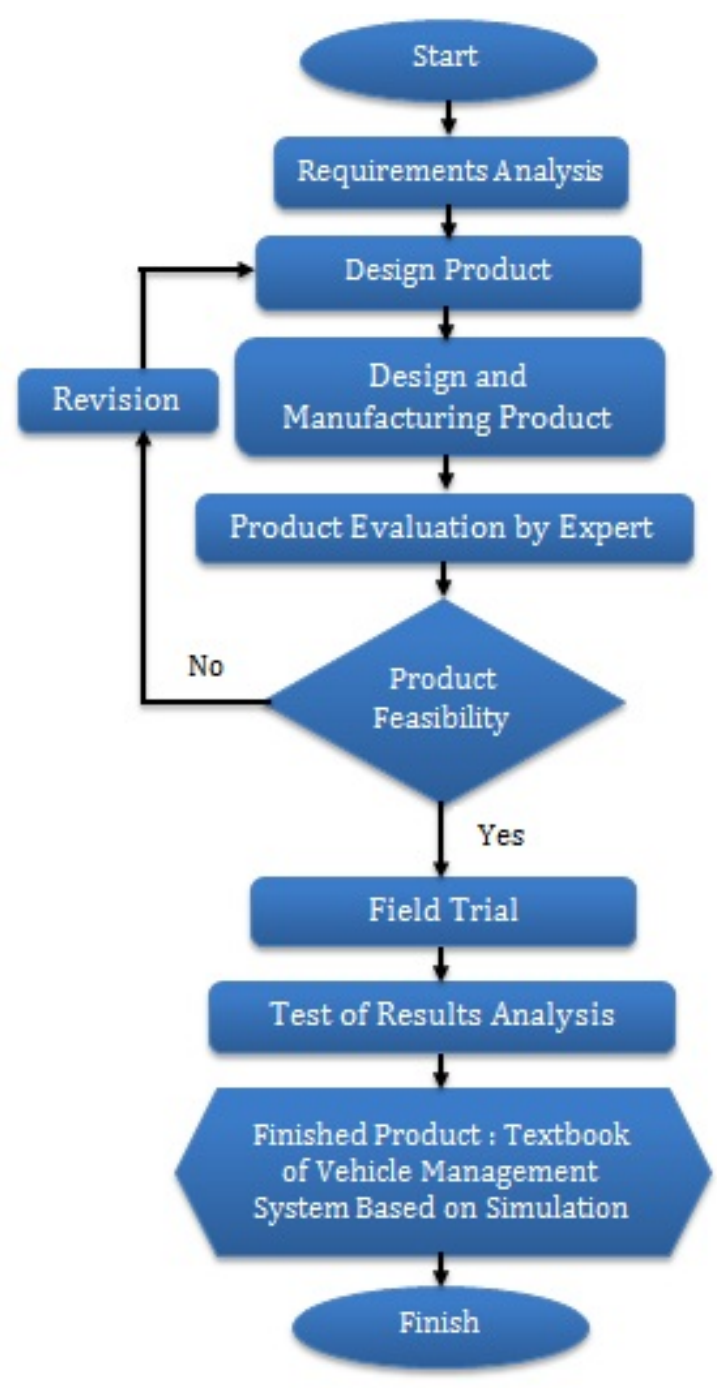

Figure 1. Research flow

The focus of this research was the development of the vehicle management system textbook and the data analysis used is descriptive. Average scores are obtained from material experts, learning device experts, and lecturers. The assessment data is then analyzed using a Likert scale calculation in the range of scores 1-4.

Table 1. Likert scale as a rating

\begin{tabular}{lc}
\hline \multicolumn{1}{c}{ Alternative Answers } & Score \\
\hline Strongly agree & 4 \\
Agree & 3 \\
Quite Agree & 2 \\
Disagree & 1 \\
\hline
\end{tabular}


Next the results of the assessment are calculated as follows.

$\%$ score $\frac{\sum \text { acquisition score }}{\sum \text { maximum score }}=\mathrm{x} 100 \%$

The percentages of the assessment score obtained then were measured using a score interpretation for the Likert scale as shown on Table 2 .

Table 2. Interpretation of the Likert scale

\begin{tabular}{cc}
\hline Percentage (\%) & Interpretation \\
\hline $\mathbf{0}-\mathbf{2 5}$ & Bad \\
$\mathbf{2 6}-\mathbf{5 0}$ & Quite good \\
$\mathbf{5 1}-\mathbf{7 5}$ & Good \\
$\mathbf{7 6}-\mathbf{1 0 0}$ & Very good \\
\hline
\end{tabular}

Research is considered successful if the questionnaire data processing results obtained scores between $51 \%$ to $100 \%$, or the criteria of "Good" or "Very Good".

\section{LITERATUR REVIEW}

\section{a. Vehicle Management System Concept}

Vehicle management system is part of the existing knowledge in the automotive world, especially in vehicle management. Today's vehicles are designed by providing very high technology elements, especially in the drive system, frame system, electricity, comfort and safety. In learning this course, it involves instrumentation of computer technology. According to Yahya (2017) explained that the technology in the vehicle today has implemented an automatic control system. A control system in which the human factor is not dominant in the control actions carried out in the system. The role of humans is replaced by a controller system that has been programmed automatically according to its function, so that it can play as humans do.

In the modern industrial world there are many control systems that utilize automatic control, especially for industries engaged in fields whose processes endanger the safety of the human soul. Vehicle management system learning in lectures requires development, especially in the design of simulation software and applications as learning media.

\section{b. Development of Teaching Materials}

Mulyasa (2006) explains the principles of developing teaching materials are validity, related to the level of suitability and materialness of competency, significance, utility, learnability, related to the possibility of the material to be studied, both related to the availability and feasibility of the material to be studied and the ease of obtaining it, interest, related to the attractiveness of the level of material, so as to encourage and arouse students' willingness to conduct various further assessments. Teaching materials or instructional materials are knowledge, skills and attitudes that students must learn in order to achieve predetermined competency standards. In detail, the types of learning materials consist of knowledge (facts, concepts, principles, procedures), skills, and attitudes or values.

The principles in the selection of learning material include: (a) the principle of relevance, (b) consistency, and (c) adequacy. The principle of relevance means that learning material should be relevant to have relevance to the achievement of competency standards and basic competencies. The principle of consistency means that there is a diversity between teaching materials and basic competencies that students must master. For example, there are four kinds of basic competencies that must be mastered by students, teaching materials that must be taught must also include four types. The principle of adequacy means that the material taught should be sufficient in helping students master the basic competencies taught. Material must not be too little, and must not be too much. If it is too little it will not help to achieve the standard of competence and basic competence. Conversely, if too much will waste time and effort unnecessarily to learn it. Likewise Ahmad (2012) explains that teaching material is material that will be taught to selected students (selected), or teaching material is material (messages) that must be learned and understood by students. So it can be concluded teaching materials are materials or subject matter that are arranged systematically, which are used by teachers and students in the learning process.

\section{c. Simulation Software}

According to Sumadi (2013) explains that software is a collection of electronic data that is stored and regulated by a computer, electronic data stored by that computer can be a program or instruction that will execute a command. The same thing was explained by Hasyim (2008), software (software) is a series 
of electronic instructions that instruct computers to perform certain tasks in accordance with the instructions given by a computer user. Simulation is the process of designing a model of a real system and carrying out experiments with this model for the purpose of understanding the behavior of the system or to formulate strategies in connection with the operating system. The basic concept of simulation is to construct teaching aids that are almost similar to the system in studying the response of each variable in a faster time and at a more economical cost (Juri, 2013).

Simulation is part of the learning multimedia presentation format. The purpose of the simulation, among others, is for training. Informatics studies that support computer simulations include modeling, system tori, software engineering and computer animation. Curtin (2011) research results show that the use of computer-based simulations before a mannequin-based simulation increases the achievement of objectives and learning outcomes. In addition to improving participant skills, completing computer-based simulations in advance can increase the confidence of participants during real-life settings achieved in mannequin-based simulations. These results are reinforced by Peffer (2015) which states for each simulation, students are tasked with solving scientific problems through investigation and hypothesis testing. After completion of the simulation, $67 \%$ of students reported changes in the way they viewed authentic science practices.

\section{RESULTS AND DISCUSSION \\ a. Results}

The results of this study are Vehicle Management System textbooks are based on the Higher Education National Standard Curriculum (SN-Dikti) owned by the D3 Automotive Engineering Study Program of the Indonusa Polytechnic Surakarta. The expected learning outcomes in the course are that students are able to master and apply vehicle stability system technology, braking system technology, suspension system technology, vehicle body technology and vehicle accessory features. In supporting RI. 4.0 learning, the design of this book is based on simulation software and uses the internet to support learning.

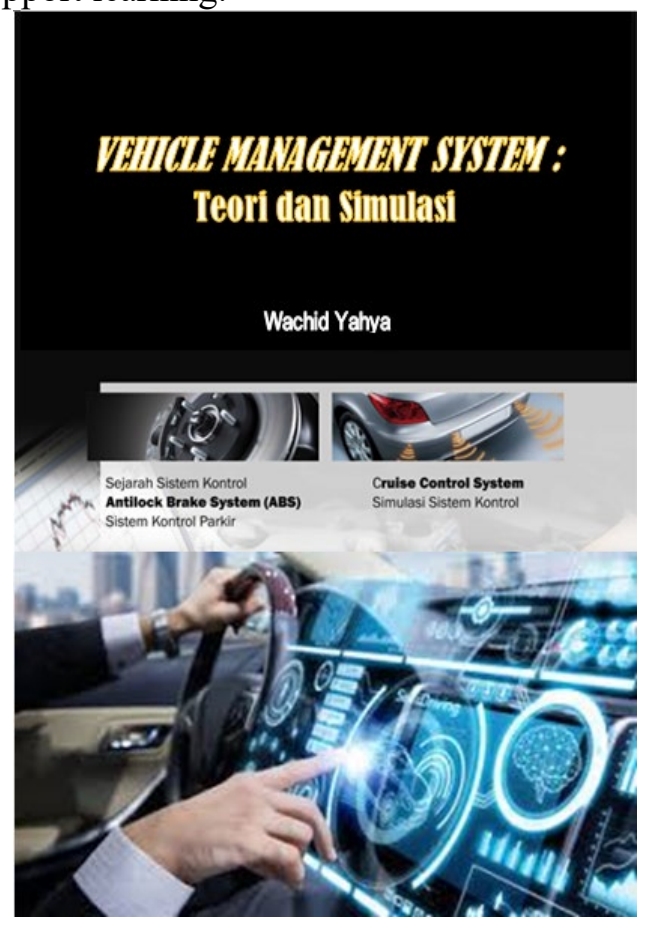

Figure 2. Display cover of textbooks

This textbook is designed using an application that can be installed on android on smartphones, the application development design uses MIT App Inventor 2 which includes simulations via video and software simulation fluidsim 3.6 and Proteus 7.07.

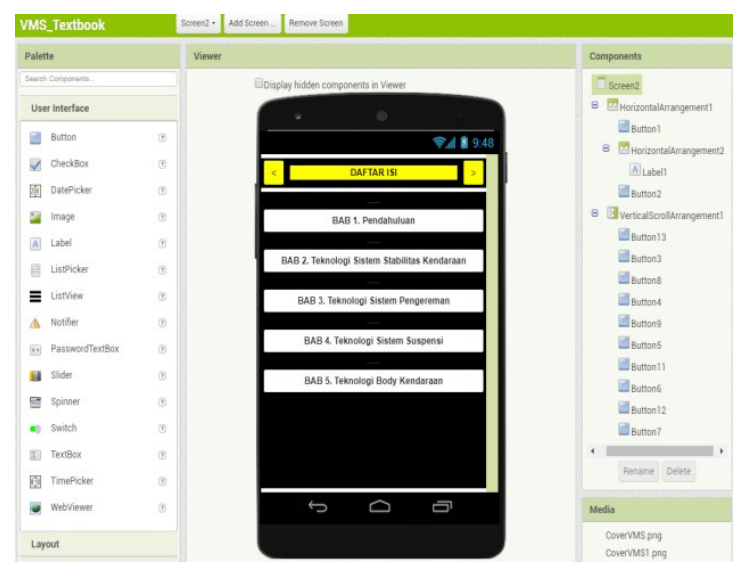

Figure 3. Display applications on Android using MIT App Inventor 2 


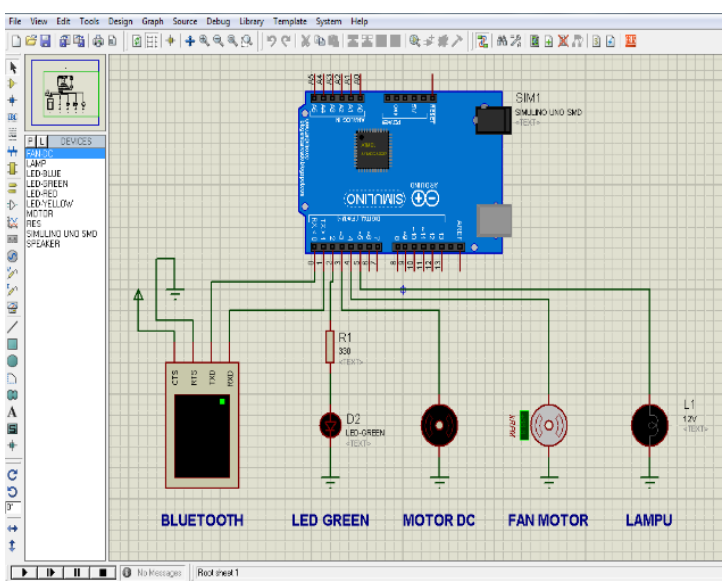

Figure 4. Proteus 7.07 simulation software

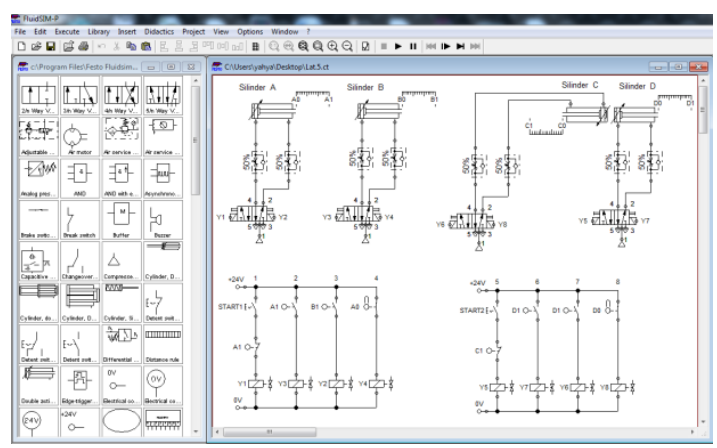

Figure 5. Fluidsim simulation software 3.6

Data obtained from the results of the validation and trial process in the field are shown on Table 3 to Table 6. Vehicle Management System textbooks based on simulation software developed are validated by material experts and learning device experts. The results of the assessment are then used as material for analysis of books that have been developed so that it becomes a product that is suitable for use.

Table 3. Results of the assessment by material experts

\begin{tabular}{lcc}
\hline \multicolumn{1}{c}{$\begin{array}{c}\text { Measured } \\
\text { aspects }\end{array}$} & Score & $\begin{array}{c}\text { Interpretat } \\
\text { ion }\end{array}$ \\
\hline $\begin{array}{l}\text { Material } \\
\text { Coverage } \\
\text { Material } \\
\text { suitability } \\
\text { Presentation } \\
\text { technique }\end{array}$ & $92,41 \%$ & Very good \\
Linguistic & $92,94 \%$ & Very good \\
\hline Average & $92,36 \%$ & Very good \\
\hline
\end{tabular}

Table 4. Results of assessment by learning device experts

\begin{tabular}{ccc}
\hline $\begin{array}{c}\text { Measured } \\
\text { aspects }\end{array}$ & Score & $\begin{array}{c}\text { Interpretati } \\
\text { on }\end{array}$ \\
\hline
\end{tabular}

\begin{tabular}{|c|c|c|}
\hline $\begin{array}{l}\text { Appropriate } \\
\text { content }\end{array}$ & $85,71 \%$ & Very good \\
\hline $\begin{array}{l}\text { Technical } \\
\text { design }\end{array}$ & $87,92 \%$ & Very good \\
\hline $\begin{array}{l}\text { Book } \\
\text { component }\end{array}$ & $88,86 \%$ & Very good \\
\hline Linguistic & $81,63 \%$ & Very good \\
\hline Average & $86,03 \%$ & Very good \\
\hline \multicolumn{3}{|c|}{ Table 5. Results of assessment by lecturers } \\
\hline $\begin{array}{c}\begin{array}{c}\text { Measured } \\
\text { aspects }\end{array} \\
\end{array}$ & Score & $\begin{array}{c}\text { Interpretat } \\
\text { ion }\end{array}$ \\
\hline $\begin{array}{l}\text { Appropriate } \\
\text { content }\end{array}$ & $81,54 \%$ & Very good \\
\hline $\begin{array}{l}\text { Material } \\
\text { Coverage }\end{array}$ & $85,29 \%$ & Very good \\
\hline $\begin{array}{l}\text { Presentation } \\
\text { technique }\end{array}$ & $87,81 \%$ & Very good \\
\hline Linguistic & $85,65 \%$ & Very good \\
\hline Average & $85,07 \%$ & Very good \\
\hline
\end{tabular}

Textbooks are introduced to students to determine responses after using books. The assessment of the field test results from the use of this book involved the second semester students of the D3 Automotive Engineering Study Program of the Indonusa Polytechnic of Surakarta academic year 2018/2019. The percentage of field test results obtained from students after using this textbook is as shown on Table 6.

Table 6. Results of assessment by students

\begin{tabular}{lcc}
\hline \multicolumn{1}{c}{$\begin{array}{c}\text { Measured } \\
\text { aspects }\end{array}$} & Score & $\begin{array}{c}\text { Interpretat } \\
\text { ion }\end{array}$ \\
\hline $\begin{array}{l}\text { Display } \\
\text { Material }\end{array}$ & $84,82 \%$ & Very good \\
$\begin{array}{l}\text { Coverage } \\
\text { Presentation } \\
\text { technique }\end{array}$ & $87,67 \%$ & Very good \\
$\begin{array}{l}\text { Linguistic } \\
\text { Average of all } \\
\text { aspects }\end{array}$ & $88,24 \%$ & Very good \\
\hline
\end{tabular}

Based on Table 6, students gave a score of 86.62 with very good interpretation.

\section{b. Discussion}

This Vehicle Management System textbook was developed through the Research and Development (R\&D) method with a model developed by Dick and Carry. The results of the assessment given by material experts, learning device experts, lecturers and students. 
The assessment obtained from the material experts is obtained an average value of 92.94 with a very good interpretation. The highest rating is given to the presentation technique with a value of $94.64 \%$. The notes given by the material experts are the scope of material that needs to be deepened, because it refers to the achievement of learning being able to apply then the learning material needs to be directed at technical matters. Furthermore, the assessment given by the learning device experts is 86.03 with very good interpretation. Appraisers provide suggestions related to linguistic aspects that need to be made dynamic and communicative. In addition, the Semester Learning Plan needs to be detailed related to the distribution of teaching materials so that more synchronized and well planned.

After subject matter expert and learning tool testings, then field testing in a limited class consisted of 2 lecturers. It obtained an average value of 85.07 with a very good interpretation. Notes given are relating to the suitability of the material in the book and the simulation software that needs to be focused on the competencies to be achieved. Thus students will focus more on understanding the material in each part of the competency being studied. Field test results to get responses from 30 students obtained an average value of 86.62 with a very good interpretation. Overall, students gave input on aspects of the display of images and videos with low resolution to be replaced with clearer and clearer pictures and videos.

Based on the results of the assessment, notes and suggestions and input from the assessors, this simulation software based Vehicle Management System textbook has been revised and improved and has the following characteristics of excellence.

a. Chapters of textbook are presented clearly and sequentially so that this book can help students learning a Vehicle Management System concept.

b. Presentation of Vehicle Management System textbook based on simulation software with 6 stages; stimulation, problem statements, data collection, data procession, verification, and generalization.

c. Learning objectives are formulated and clearly conveyed to students so that students can be directed when using books as a medium of independent learning whether learning in the classroom or outside the classroom. Mulyasa (2006) on of the principles of developing teaching materials is learnability which is related to the possibility of the material to be studied, both related to the availability and feasibility of the material to be studied and the ease of obtaining it.

d. The availability of the final formative test of learning activities, the final evaluation of books, if students operate the book online, the students' answers will be sent automatically to the lecturer email, so the lecturer can monitor the activities of their students in the use of books.

e. The displayed animations were added with text as an explanation and audio-visual explanation that helps students to be more interested in the contents of the material.

f. Media on book content is presented in the context of everyday life taken from a video review of vehicle technology, thus enabling students to better understand the usefulness of learning the Vehicle Management System course in everyday life and are motivated to do observing activities, as well as assist students in illustrating a incident. The media content presented in this book supports the understanding of student concepts, and is able to attract students to read and study this book. This textbook is integrated using an application that can be installed on a smartphone, the application development design uses MIT App Inventor 2 which contains simulations via video and Fuidsim 3.6 simulation software and Proteus 7.07. According to Juri (2013) simulation can be an aids in studying in a faster time and at a more economical cost. Curtin (2011) also found that the use of computer-based simulations increases the achievement of objectives and learning outcomes.

\section{CONCLUSIONS}

I The results of this research product are the creation of a Vehicle Management System course textbook integrated with simulation software namely Proteus version 7.07 and Fluidsim version 3.6. Besides this book is also designed in the form of an android application using MIT App Inventor 2. The assessment showed that the percentage of achievements 
was $92.94 \%$ of the material experts, $86.03 \%$ of the learning device experts, $85.07 \%$ of the lecturers, and $86.62 \%$ of the students. Based on these results it can be concluded that the module developed which is a Vehicle Management System textbook based on simulation software has met the criteria very good. This textbook has advantages from aspects of learning that are in accordance with learning 4.0, namely by combining theory and simulation that can be accessed via smart phones or computers connected to the internet.

\section{REFERENCES}

Ahmad, Zainal Arifin. 2012. Perencanaan Pembelajaran. Yogyakarta: Pedagogia.

Hasyim.(2008). Buku Pintar Komputer . Kriya Pustaka.

Juri, Faisal. 2013. Aplikasi Untuk Simulasi Pola Pergerakan Strategi Bermain Bola Tangan Berbasis Adobe Flash. Sekolah Tinggi Manajemen Informatika dan Komputer. Amikom Yogyakarta.

Kagermann, H., Wahlster W., Helbig, J. (2013). Recommendations for implementing the strategic initiative Industrie 4.0: Final report of the Industrie 4.0 Working Group.

Klingenberg, Cristina Orsolin and Antunes, José Antônio do Vale. 2017. Industry 4.0: what makes it a revolution?. Paper presented in EurOMA 2017.

Lindsay B. Curtin, dkk. 2011. Computerbased Simulation Training to Improve Learning Outcomes in Mannequin-based Simulation Exercises. Journal of Pharmaceutical Education 2011; 75 (6).

Peffer, Melanie E., dkk. 2015. Science Classroom Inquiry (SCI) Simulations: A Novel Method to Scaffold Science Learning.

DOI:10.1371/journal.pone.0120638

March 18, 2015.

Mulyatiningsih, Endang. (2013). Metode Penelitian Terapan Bidang Pendidikan. Bandung: Alfabeta.

Mulyasa E. 2006. Kurikulum Yang Disempurnakan. Bandung: PT Remaja Rosdakarya.

Sumadi. 2013. Software Perangkat Lunak Komputer Belajar Komputer.

Thai, Huyunh Van and Anh, Thi Kim. 2017. The 4.0 Industrial Revolution Affecting
Higher Education Organizations' Operation In Vietnam. International Journal of Management Technology Vol.4, No 2, pp. 1-12, October 2017.

Yahya, Wachid. 2018. Desain Media Pembelajaran Sistem Kontrol Elektropneumatik Berbasis Programmable Logic Controller. Jurnal Pendidikan Teknik Elektro. Volume 03, Nomor 01, March 2018, 42-49.

Yahya, Wachid. 2017. Sistem Kontrol Otomotif. Yogyakarta : Deepublish.

Wermann, Jeffrey. 2019. Using An Interdisciplinary Demonstration Platform for Teaching Industry 4.0. Procedia Manufacturing 31 (2019) 302-308. 